This item was submitted to Loughborough's Research Repository by the author.

Items in Figshare are protected by copyright, with all rights reserved, unless otherwise indicated.

\title{
Winning wars, building (illiberal) peace? The rise (and possible fall) of a victor's peace in Rwanda and Sri Lanka
}

\section{PLEASE CITE THE PUBLISHED VERSION}

http://dx.doi.org/10.1080/01436597.2015.1058150

\section{PUBLISHER}

(C) 2015 Southseries Inc. Published by Taylor and Francis

\section{VERSION}

AM (Accepted Manuscript)

\section{PUBLISHER STATEMENT}

This work is made available according to the conditions of the Creative Commons Attribution-NonCommercialNoDerivatives 4.0 International (CC BY-NC-ND 4.0) licence. Full details of this licence are available at: https://creativecommons.org/licenses/by-nc-nd/4.0/

\section{LICENCE}

CC BY-NC-ND 4.0

\section{REPOSITORY RECORD}

Piccolino, Giulia. 2019. "Winning Wars, Building (illiberal) Peace? the Rise (and Possible Fall) of a Victor's Peace in Rwanda and Sri Lanka". figshare. https://hdl.handle.net/2134/22708. 


\section{Winning wars, building (illiberal) peace? The rise (and possible fall) of a victor's peace in Rwanda and Sri Lanka}

Review of:

Remaking Rwanda: State Building and Human Rights after Mass Violence. By Scott Straus and Lars Waldorf (eds.), Madison, University of Wisconsin Press, 2011. 382 pp., \$26.95 (paperback) (ISBN 978-0-299-28264-6).

Rwanda Fast Forward: Social, Economic, Military and Reconciliation Prospects. By Maddalena Campioni and Patrick Noack (eds.), Basingstoke, Palgrave Macmillan, 2012. 283 pp., £63.00 (hardback) (ISBN 978-0-230-36048-8).

Political Governance in Post-Genocide Rwanda. By Filip Reyntjens, Cambridge, Cambridge University Press, 2013. 320 pp., £60.00 (hardback) (ISBN: 978-1-10704355-8).

Conflict and Peacebuilding in Sri Lanka Caught in the Peace Trap? By Jonathan Goodhand, Benedikt Korf, Jonathan Spencer (eds), London, Routledge, 2011. 256 pp. $€ 108.40$ (hardback), €41.16 (paperback) (ISBN: 978-1-136-87626-4).

Liberal Peace in Question: Politics of State and Market Reform in Sri Lanka. By Kristian Stokke and Jayadeva Uyangoda (eds.), London, New York: Anthem Press, 2011. 216 pp. $\$ 99.00$ (hardback) (ISBN: 978-1-843-31896-5).

\section{Giulia Piccolino}

Institute of African Affairs, German Institute of Global and Area Studies, Hamburg, Germany

Neuer Jungfernstieg 21, 20354, Hamburg. Email: giulia.piccolino@giga-hamburg.de Author Original Version. The final version will be available on Third World Quarterly (CTaylor and Francis) at http://dx.doi.org/10.1080/01436597.2015.1058150 .

\footnotetext{
Abstract

The literature on peacebuilding dedicates very little space, empirically and theoretically, to countries that are emerging from a war waged to a decisive outcome. This review article looks
} 
at Sri Lanka and Rwanda, two countries where a victorious leadership has led the process of post conflict reconstruction, largely by employing illiberal means. It looks at the effect of decisive war on statebuilding and at the role of local agency and of illiberal practices in a postvictory context. It concludes assessing the global significance and long-term sustainability of post victory illiberal statebuilding.

\section{Acknowledgements}

I would like to thank Matthias Basedau for useful comments on this paper. This article was previously submitted to another journal, and the comments of one of the anonymous referees greatly helped me to revise it. This article was written while benefitting of a postdoctoral fellowship funded by the Alexander Von Humboldt Stiftung.

\section{Introduction}

Victory has been for most of history the usual form of civil war termination but its impact on the consolidation of peace is poorly understood. Although the current postconflict peacebuilding and reconstruction literature offers a lot of fascinating insights, it has been, up to now, overwhelmingly focused on the 'liberal peace'. Both supporters and critics of the liberal peace argue that this is a political project promoted by - usually Western - outsiders and strongly based on the assumption that institution-building inspired to a Weberian ideal of state and political and economic liberalization are the most secure avenues for peace. The debate has been very much framed by the division between supporters of the liberal peace, such as Roland Paris, ${ }^{1}$ and critical scholars, who argue that liberal peace-building is a top-down, technocratic exercise that displays insensitivities to the local context. ${ }^{2}$

However, the emphasis on the liberal peace has encouraged both orthodox and critical scholars to define post-conflict countries in term of their deviation from an ideal $^{3}$ - the liberal-democratic one, in the first case, or more articulated conceptions of 'emancipatory', 'popular' or 'every day' peace on the other. This tendency is confirmed by the depiction of the peace prevailing in some post conflict countries as void or 'virtual'. 4 This normative agenda has distracted scholars from the key questions at stake: how do countries recover from violent conflicts? How do they rebuild their institutions? Why are some outcomes stable and other not, in spite of the apparent 
similarity of the means employed? Who has gained and who has lost in post-conflict environments?

If peacebuilding is understood as the problem of achieving sustainable peace and consolidating political order after a conflict, then it is an issue that largely predates the birth of peacebuilding as it has been conceptualized by the United Nations (UN), international agencies and donors since the 1990s. Historically, many peacebuilding efforts have been unrelated to international intervention and to the promotion of liberal values. However, calls by Jeremy Weinstein to look at "autonomous recovery", defined as a process in which states achieve a lasting peace, a systematic reduction in violence, and post-war political and economic development in the absence of international intervention" 5 and by Ricardo Soares de Oliveira to explore "illiberal peacebuilding", "a process of post-war reconstruction managed by local elites in defiance of liberal peace precepts"6 have not been, up to now, properly addressed.

Moreover, as Suthaharan Nadarajah and David Rampton argue in their critique of the use of hybridity in peacebuilding studies, the liberal peacebuilding literature has downplayed the "significant seam of desire for "modernization and nationalism in the Third World', which still propels in many contexts, local and national, ideological conceptions of and desire of statehood". ${ }^{7}$ State elites in post conflict countries have been often dismissed as authoritarian and corrupt by the peacebuilding literature, while ignoring their ambitions for statebuilding and economic modernization.

Many cases underexplored by the peacebuilding literature consist of countries where a civil war has terminated with the victory of one of the warring parties. Statistically, victory has been found to correlate with more stable peace with respect to negotiated settlements. ${ }^{8}$ A series of stylized assumptions about the mechanisms through which victory can produce durable peace appears in the quantitative literature on civil war termination. It is usually argued that victory has a 'repressive' peacemaking effect, disrupting the organizative structure of the loser and exhausting resources for waging wars. ${ }^{9}$ Because losers are seriously weakened in terms of capacities but also of moral stand, they will be unlikely to challenge again the victor on the battlefield. More controversially, both the pioneering work of Licklider ${ }^{10}$ and the provocative research of Monica Duffy Toft ${ }^{11}$ have advanced the hypothesis that, at least under certain conditions, victory might have also a 'transformative' potential. The victor is in a stronger position with respect to a party to a negotiated settlement: he is not under constant pressure to compromise with the loser or with third party brokers. In the short 
term, this might encourage authoritarianism, but, in the medium and long term, the victor can boost statebuilding and economic development by implementing bold and possibly unpopular reforms.

Much of the literature that attributes to victory a positive impact on post war peace draws from the seminal work of Charles Tilly, who emphasized the role played by war and military violence in the emergence of the state in Europe. ${ }^{12}$ While mainstream International Relations literature since the 1990s has tended to highlight the relation between violent conflict and state failure, the influence of Tilly's ideas is patent among scholars of developing countries, particularly Sub-Saharan Africa. ${ }^{13}$ These authors have argued that misguided external attempts at building states can lead to unsustainable outcomes and superficial institutional isomorphism, while, under certain conditions, brutal or predatory processes may contribute to peace and to the consolidation of institutions.

Classical strategic studies, however, have expressed more scepticism about the easiness with which a victory on the battlefield would translate in post-war stability. ${ }^{14}$ They stress that victory is also a political and intersubjective process, and that an active engagement is required from victors, if they want to consolidate their gains and build a sustainable political order. Even if illiberal means can be employed in the pursuit of peace, violence and force alone are not sufficient. ${ }^{15}$ In this sense, victors of civil wars have been historically the first actors to face statebuilding and peacebuilding challenges, long before these terms entered the international jargon.

\section{The victor's peace in Rwanda and Sri Lanka}

Although the victor's peace is largely under-theorized, the existing literature offers sound empirical case studies of post-conflict societies that have experienced a civil war terminated with a military victory. Post-conflict reconstruction in these countries often ignores - or is sometimes openly defiant of - liberal norms. Rwanda and Sri Lanka offer a privileged viewpoint to explore the making of a 'victor's peace' by, respectively, insurgents and state elites. Both countries have a long and very violent history of conflict, terminated in Rwanda in 1994 with the genocide and the victory of the Rwandan Patriotic Front (RPF) and in 2009 in Sri Lanka with the defeat of the LTTE (Liberation Tigers of Tamil Elan) by the Mahinda Rajapakse government. The two conflict have been driven by a major ethnic cleavage - between Hutu and Tutsi and between Sinhalese and Tamil respectively. 
Dissimilarities, however, should also be stressed. The Rwandan conflict pitted an insurgency initiated by the Tutsi diaspora against the Hutu-controlled government. It was an ethnic conflict without a territorial dimension and ended tragically with the 1994 genocide, which paradoxically facilitated the victory of the RPF. In the case of Sri Lanka, the central government, controlled by the Sinhalese majority, opposed the LTTE secessionist insurgency: the conflict had the opposite outcome, with the incumbent government defeating the LTTE and managing to keep the state united.

The three books on Rwanda represent a laudable effort to shift the academic and policy debate on the country from the focus on the 1994 genocide to the political and economic evolution of the last twenty years. Rwanda's experience with post-conflict reconstruction is a highly contentious topic. A dispassionate discussion is a most needed one, given that the international image of the country in recent years has oscillated between that of a 'model country' and of a grim dictatorship. The cleavage between Rwanda's supporters and detractors has, unfortunately but perhaps inevitably, not spared the academic community. This is particularly evident in Reyntjens' book, whose explicit aim is to denounce the authoritarian character of Rwanda's political governance and the dangers that it poses to the future of the country.

Given the recent conclusions of the Sri Lankan conflict, the two books on Sri Lanka focus more on the failure of the 2002-2004 peace process, which was based on the typical tenets of liberal peacebuilding, than on the construction of an illiberal alternative. In spite of the fact of being based on research predominantly carried before the end of the conflict, however, they are helpful in understanding how an alternative and illiberal peace emerged in Sri Lanka and which material and ideological forces sustained it.

The first important contribution of the five books under review is an empirical one. They have been written by authors that have extensive experience in and about the countries in question and place squarely the two countries' trajectory of war and postconflict reconstruction within local history and politics - something that the more theoretical oriented peacebuilding literature too often fails to do. Filip Reyntjens was unable to carry out field research, because barred from access for having pointed out at the authoritarian evolution of the Rwandan government in 1995. Nevertheless, his book is empirically sound, drawing from a long engagement with Rwanda (the author served as expert witness in several genocide trials), public sources and confidential material that Reyntjens has been able to obtain through his personal connection. 
Four of the publications under review are edited books. Although this format of academic publication has been often criticized, it offers to the editors the opportunity to combine different levels of analysis (the international, the national, the local) and to draw from the expertise of specialists of different aspects of political and economic governance.

Some shortcomings of the edited book format are, of course, also evident. Remaking Rwanda features a large number of contributions, forcing scholars that in some cases have dedicated many years to researching Rwanda to condense their argument into a few pages. Rwanda Fast Forward suffers from the rather anodyne introduction by Maddalena Campioni and Patrick Noack and, compared to the other edited collections under review, is the most uneven one in terms of quality, although it contains several thought provoking essays, particularly the contributions of three young scholars from the University of Oxford - Andrea Purdeková, Will Jones and Harry Verhoeven. As an inevitable consequence of the different political and academic situation in the two countries, the books on Sri Lanka do a better job at integrating the contributions of local researchers. However, Remaking Rwanda and Rwanda Fast Forward also offer a diversity of perspectives by integrating contributions from practitioners, of which the more interesting are the ones on transitional justice.

In terms of theoretical and comparative contribution, Remaking Rwanda and the two books on Sri Lanka are the most explicit in trying to reconnect the case study to global debates on post-conflict reconstruction, although the theoretical interrogations posed in the introductory chapters are not addressed by all the contributors. Straus and Waldorf do not engage with the literature on the liberal peace but they criticize problem-solving works that use narrow definitions of failure and success. They argue that the Rwandan case demonstrate the need for "a more complex model to understand the trajectory - not merely the outcome - of post conflict recovery". ${ }^{16}$ Both Goodhand and Korf and Stokke retain the concept of liberal peace understood as the belief that peace can be achieved through negotiations between rational and self-interested parties and consolidated by fostering democracy and market economy. However, they are skeptical about conceptualizing the liberal peace as an overwhelming technology of power and assuming a clear cut divide between the peacebuilders and the targets of intervention. Criticizing "Foucauldian readings of liberal peacebuilding" that tend to downplay local agency, they advocate more attention for the "acts of translation, composition and resistance through which a policy idea is shaped and translated in the 
domestic arena". ${ }^{17}$ Kristian Stokke on his part argues that the Sri Lanka peace process and war should be interpreted within a twofold global shift - a discursive shift in the understanding of insurgencies by the West and a geopolitical shift from the Western world to the rising Asian powers. ${ }^{18}$

Beyond the stated intentions of the authors, the reader will find in the five books under review many arguments that challenge conventional wisdom about the hegemony of the liberal peace, the nature of contemporary warfare, the role of national elite actors in post-conflict reconstruction. It is perhaps unfortunate that, because of their nature of single case studies, the books might fail to capture the attention of more theoretically oriented scholars. I concentrate here on four issues about which the books can offer insights of more general theoretical and comparative interest: the link between war and statebuilding, the interplay between international intervention and local agency and the liberal or illiberal character of peace. An analysis of these issues shows the inadequacy of the current frameworks of 'liberal peacebuilding' and 'hybrid peace' in understanding victory to peace transitions and the material and ideological forces that sustain them. I conclude by assessing the global implications and sustainability of Rwanda and Sri Lanka's experiences.

\section{Civil war and statebuilding}

Much of the discourse on civil wars from the 1990s on has pointed at the decline of conventional warfare and at the link between 'new wars' and state failure. However, the authors of the books under review show that many stereotypes about warlordism and state decay in contemporary conflicts do not apply easily to Rwanda and Sri Lanka. Charles Tilly's ideas about the link between war making and state making appear to retain some validity with respect to conflicts waged with conventional means by actors that are cohesive, rather symmetric in force and face what they perceive as an existential threat.

The conflicts in Rwanda and Sri Lanka displayed these features. In Rwanda, "the RPF is more analogous to a regular army than almost any other African rebel movement in recent history"19 and their antagonists, the Forces Armées Rwandaises, stuck to a "fairly high professional standard for an African army" and "kept their cohesion even in defeat". ${ }^{20}$ In the end, the RPF came out from the war as a formidable military organization and, after gaining power, administered the state with the same discipline and sense of hierarchy developed from war making. ${ }^{21}$ 
In Sri Lanka, the LTTE had completed its evolution from an insurgent organization to a conventional army long before the resumption of hostilities in $2006 .{ }^{22}$ It also exercised a monopoly of violence on substantial parts of the country, building a 'proto-state' during its long occupation of the North, with many of the trappings of empirical statehood. ${ }^{23}$ The last phase of the Sri Lankan conflict featured recognizable frontlines, aerial bombings, heavy artillery and was fought with professionalism and courage - although ruthlessly - by the Sri Lanka Army (SLA) and the LTTE. ${ }^{24}$

The two conflicts also displayed some features of an international, rather than an internal conflict. The RPF was composed by former refugees who had grown up outside the country, spoke English, and had at least initially the backing of Uganda. They were thus widely perceived as 'foreigners' in Rwanda, even by Tutsi survivors. ${ }^{25}$ Analogously, because of de facto territorial control of the LTTE on parts of the country, Stokke argues that the 2002-2004 peace process in Sri Lanka resembled "interstate conflict resolution between two nations with standing armies and incompatible state formation projects". ${ }^{26}$ The 'state formation' character of the two conflicts and the totalitarian understanding of their goals by the protagonists might have been reciprocally reinforcing. ${ }^{27}$

These characteristics of the conflict help explaining why war has contributed to state formation, rather than failure, in both countries. Indeed, Rwanda and Sri Lanka seem to show the limits of the current 'fragile state' discourse: they have been unable for most of their history to institutionalize an inclusive 'social contract' and avoid high levels of violence, but they are both relatively strong states in terms of their coercive and administrative capacities.

In the case of Rwanda the continuation of hostilities in another form after the end of the 1994 civil war should also be considered when analyzing the connection between war and institution building. The RPF was first confronted by a cross border insurgency, staged from the Eastern Democratic Republic of Congo (DRC) by former soldiers and militia members loyal to the former regime. The conflict with exiled Rwandan Hutu elements, regrouped as the Forces Démocratiques de Libération du Rwanda (FDLR), has continued for many years on Congolese soil and through proxy armed groups. Rwanda invaded twice the DRC, in 1996 and in 1998, and although it officially withdrew in 2002, it has continued to support covertly Tutsi Congolese rebel groups. ${ }^{28}$ The perception of the RPF that Tutsi face a continuous threat in the Great Lakes region cannot be simply discounted as a cover for economic motives, although 
the latter might have played a role in explaining Rwanda's involvement in the Congo. As in other countries, this perception might have acted in Rwanda as a further stimulus for the state and institution building process. ${ }^{29}$

\section{A "domestic" peace?}

The centrality of the "agency of domestic constituencies vis-a-vis the international community" 30 is another main common theme of the books under review. Such a centrality is all more noticeable as Rwanda and Sri Lanka are two small states lacking large supplies of natural resources. The contributors do not deny the importance of international involvement. Although in neither country was a major peacekeeping mission deployed, international peacebuilders were present as peacemakers, diplomatic partners and donors. Rwanda, with an economy devastated by the genocide, has financed for many years a large portion of its state budget through development aid. In Sri Lanka, the 2002-2007 peace process has been internationalized at an unprecedented level, compared with previous attempts at negotiating an end to the conflict. Yet, the Rwandan and Sri Lankan political elites have retained substantial control over their wartime and peacetime choices.

As Eugenia Zorbas and Rachel Hayman's chapters in Remaking Rwanda show, ${ }^{31}$ Rwanda is a quite impressive case of a country heavily aid dependent that has managed to maximize its agency and resist international demands - especially demands for democratization. On virtually every domain - from elections, to transitional justice, to agrarian development and economic policies - the RPF has imposed its views on the international community. Filip Reyntjens' book suggests that the Rwandan government has become attuned at manipulating liberal platitudes, such as 'good governance' and 'gender equality', without endorsing the more substantial components of political liberalism (p. 187). However, the relative benevolence that Rwanda has faced could be a product not only of the 'genocide credit' that the RPF has enjoyed, but also of the fact that many international actors have been eventually persuaded by the RPF argument that statebuilding and development should be given priorities in the Rwandan context on democratic freedoms and human rights. Indeed, the case of Rwanda has very much fed into recent political economy debates, where the country has been treated as a model of African authoritarian developmental state. ${ }^{32}$ Such a view of Rwanda as a model has been actively boosted by the RPF itself. One example is an international meeting 
convened in 2011 by the Rwandan authorities in Kigali with the collaboration of the UN Peacebuilding Commission to discuss the lessons' from the country's experience. ${ }^{33}$

Even in Sri Lanka, the successive national governments have controlled the key aspects of the peacemaking and peacebuilding process. The most evident case has been the decision of Mahinda Rajapaksa to restart the conflict, imposing his view to donors and diplomatic partners who had initially supported enthusiastically the peace process. ${ }^{34}$ However, the ability of Sri Lankan elites to retain agency also emerges from Höglund and Svensson's chapter on peace negotiations in Liberal Peace in Question. The two scholars notice that the very internationalization of the peace process in Sri Lanka arose from the internal demand of the warring parties. Norway was welcomed as a mediator because of its non intrusive "peace ownership approach", while the government and the LTTE embraced a type of peace process that gave priority to humanitarian aid over negotiations about the political causes of the conflict. ${ }^{35}$

The cases of Rwanda and Sri Lanka confirm that gaining diplomatic respect remains one central preoccupation of victors of contemporary wars, ${ }^{36}$ especially as victory in internal conflict tends to be perceived as less legitimate than a negotiated settlement. This problem has not affected too much the RPF, whose enemies had been internationally disqualified because of their responsibility in the genocide. Choosing to embark in a military solution was much more problematic for the Rajapaksa government in Sri Lanka, since the international community had been a key supporter of the 2002-2004 negotiations. The government employed a twofold strategy: on the one hand, it sought alliance with countries with very different views on human rights and international intervention, such as Iran, Pakistan, Russia and China. ${ }^{37}$ On the other hand, it successfully reframed its campaign within the geopolitics of global security, eventually pushing the West to "accept the sovereign state's right to deploy military forces against an internationally banned terrorist organization". ${ }^{38}$

Thus, local actors in Rwanda and Sri Lanka have not just 'resisted', as in many accounts that portray a binary opposition between international peacebuilders and national actors. They have translated and readapted international ideas. They have also engaged in efforts, to some extent successful, to project their own views on the international stage and reshape global discourses on conflict and peacebuilding.

Interpretations of peace and statebuilding as processes marked by a clear divide between the 'international' and the 'local' (or even the 'local local') prove however limiting for understanding Rwanda and Sri Lanka's post colonial reality, where the 
importation of foreign ideas and practices largely predates recent experiences with peacebuilding. ${ }^{39}$ Ideologies of 'tradition' and 'local authenticity' that have underscored conflict and post war statebuilding in Rwanda and Sri Lanka and have been agitated by the Rwandan and Sri Lankan elites in opposition to the 'liberal peace' have themselves been forged in a context of global circulation of ideas and practices. Through its official discourse, the RPF has expressed its nostalgic longing for Rwanda's pre-colonial past, depicted as an ideal era of just rule and ethnic harmony, and represented the 1994 genocide as the outcome of ethnic divisions imported by colonialism. It has also insisted on the 'authenticity' of its gacaca court transitional justice system. ${ }^{40}$ However, the RPF worldview, to which Straus and Waldorf apply James Scott's concept of "high modernist ideology", ${ }^{41}$ is by no mean straightforwardly 'traditional'. The RPF has been deeply shaped by ideas of Western and Marxist-Leninist origin about the state, economic development and the transformative mission of political elites. Such ideas, coupled with Rwanda's authoritarian history, the RPF military past, its sense of estrangement with respect to the population it was called to rule have coalesced in producing an extreme version of developmentalist ideology. As Andrea Purdeková puts it in Rwanda Fast Forward, the government aims at "forging the perfect development subject" modelled on a militarized imaginary of loyalty, combativeness, willingness to subordinate its interests to a wider goal". ${ }^{42}$ Newbury, Ansom and Thomson's contributions complete the picture, highlighting the deeply paternalistic and elitist character of the RPF ideology, based on contempt for ordinary Rwandan peasants and for their locally rooted knowledge. ${ }^{43}$

The politics of Sinhala authenticity that has underscored Sri Lanka's rejection of the liberal peace, by contrast, is much more embedded in diffused popular imaginaries. The discourse of Sinhalese nationalism "privileges the rural sphere, but more specifically the peasantry, the 'sons of the soil' and village life, as the morally authentic and purified core of the Sinhala nation". 44 The "alternative governamentalities" of Sinhalese and Tamil nationalism have replaced the faith of the liberal peace in rational individuals with "an emphasis on ethnonationalist collectivities and group rights". ${ }^{45}$ However, Sinhalese nationalist ideology has been in reality forged in the post-colonial period. It should be seen in the context of Sri Lanka's distinctive economic policies, where the liberalization of the economy has not resulted in a roll back of the state or a cut of social spending but has left "welfare statism" intact. ${ }^{46}$ Patronage policies have fused with nationalism, producing "a socio-political culture in which many of the South 
look to a paternalistic state as a munificent centre for the protection of the integrity of the Sinhala nation". ${ }^{47}$

\section{The liberal/illiberal divide}

Rwanda and Sri Lanka show that the identification of the international with the liberal and of the local with the illiberal is also problematic. ${ }^{48}$ As peacebuilding scholars recognize, the global discourse of peacebuilding is not a homogenous one. After the 11 September 2001, even in the West, the Global War on Terror and the preoccupation for statebuilding have significantly watered down the concern for promoting liberal values. While critical authors include statebuilding and the US engagement in Iraq and Afghanistan in their criticism of the 'liberal peace', such as in Heathershaw's idea of a 'tripartite' liberal peace discourse (2008) on in Richmond 'strands' of peacebuilding (2005), it is dubious that 'liberal' is the right definition for a peace strictly identified with statebuilding and with conservative ideas of order and stability. The RPF and the Rajapaksa government have appealed to these illiberal aspects of the peacebuilding discourse to justify the use of illiberal means in the pursuit of peace and the priority given to stability and development over democratic freedoms. As Western states can alternatively support liberal or illiberal value, the case of Sri Lanka show that the same is true for local political elites, which were deeply divided between partisans of liberal reforms and nationalists advocating a military solution.

Rwanda and Sri Lanka have a very different historical experience, when it comes to the existence of a democratic tradition. Rwanda's authoritarianism should be understood within a long history of reinforcement of state power at the expenses of political accountability - in an evocative local metaphor, the "ruler's drum" vis à vis the "people's shout". ${ }^{49}$ The liberal agenda has been moreover seriously compromised in Rwanda by the fact that the only phase of political liberalization in its history is seen as having paved the way to the genocide. It is thus not very surprising that, in spite of rhetorical claims, Rwanda has gradually reverted to illiberal governance after the military takeover of the RPF. However, the RPF's illiberalism also shows some distinctive characters, which are extensively discussed by the books under review.

Reyntjens, in particular, makes of the authoritarian practices of the Rwandan regime the focus of his book. He is able to bring together several aspects of Rwandan governance that are often treated in isolation, such as transitional justice, relationships with donors and the management of information, showing the single underlying logic 
behind them. Whether Rwanda is an 'outlier' or is representative of a wider trend, his portrayal of Rwanda's electoral autocracy is a salutary corrective to the over-optimistic but popular view that African countries might democratize by holding periodic polls. It is difficult to disagree with his assessment that "Rwanda is not an average African dictatorship" but "a place where everything is excessive" (p. 253). However, Reyntjens' exclusive preoccupation with denouncing the violent practices of the RPF is eventually damaging to the book. The author eschews a not only theoretical but also normative key question - is there a connection between the successes of the RPF at statebuilding and economic reconstruction and its authoritarian nature? The sequence of details about the RPF's quasi-absolute grip on politics and civil society that Reyntjens provides risks in the end to sound repetitive and redundant. The book would have been more effective, even as a denunciation of the RPF's authoritarianism, if Reyntjens would have devoted some space to discuss the basis for an alternative to the current order, or to suggest to the international community an appropriate course of action.

Remaking Rwanda and Rwanda Fast Forward are more successful in accounting for the complexity of the Rwandan experience. Campioni and Noack's rosy depiction of Rwanda in the introduction is counterbalanced by several critical contributions, such as Susan Thomson's research on the views of ordinary peasants. ${ }^{50} \mathrm{In}$ contrast to Reyntjens, both Straus and Waldorf's introduction and Jones' and Verhoeven's chapters in Rwanda Fast Forward make the argument that the authoritarian character of the RPF and its successes at post-conflict reconstruction must be seen in this connection. Straus and Waldorf argue that the RPF regime is carrying a top down experiment of "political, economic and social engineering" 51 coupled with "sophisticated authoritarianism". 52 Jones and Verhoeven underscore that the RPF remains at its core a "military organization" 53 with an "astonishing small social basis within Rwanda". ${ }^{54}$ Coupled with an experience of combat where violence was used as an effective transformative tool, these characteristics have made the RPF particularly impermeable to democratic socialization - although adroit at playing the donors' language when it suits it.

Sri Lanka has, in contrast to Rwanda, a long experience with competitive politics, stretching back to decolonization. In Sri Lanka's post-colonial context, the importation of liberal ideas and practices from the West largely predates the contemporary peacebuilding process. However, the country also shows how, in real existing democracies, liberal and illiberal features might coexist and undermine in the 
end the liberal peace project. Stokke's account of the history of post-independence Sri Lanka shows how electoral politics paradoxically reinforced ethnic animosity and neopatrimonialism. In 2002-2003, the success of the liberal peace in Sri Lanka was predicated on the alignment of Prime Minister Ranil Wickremesinghe and his United National Front (UNF) coalition with the international liberal peace agenda. ${ }^{55}$ Donors enthusiastically supported Wickremesinghe but failed to see that the UNF's views were not universally shared across Sri Lanka and to anticipate the growing influence of Sinhala nationalist parties. Moreover, the close identification of the liberal peace agenda with the UNF government proved damaging in a context of increasingly strained relationship between Wickremesinghe and then president Chandrika Kumaratunga.

Both Conflict and Peacebuilding in Sri Lanka and Liberal Peace in Question also notice that, in contrast to the international expectation that the different components of the liberal peace might be self-reinforcing, the Prime Minister's plans for economic reform, which constituted the centerpiece of his programme of government, were one of the major causes of his failure in peacemaking. His programme of economic liberalization failed to generate immediate benefits for the population at large, especially in the Sinhalese South, and was one of the main reasons for Wickremasinghe's electoral defeat and, ultimately, for the failure of the peace process. ${ }^{56}$

It was in this context, and thanks, paradoxically, to the dynamics of electoral democracy, which brought Mahinda Rajapaksa to power, that the illiberal alternative emerged from the ruins of the peace process. Rajapaksa projected Sri Lanka in a "new world of illiberal peacemaking". ${ }^{57} \mathrm{He}$ betted on the Sri Lankan state's ability to defeat the LTTE by sheer force - an attempt that some of his predecessors had failed, but this time succeeded for a unique combination of favourable factors. The SLA's victorious counterinsurgency campaign was however conducted in disregard of human rights norms and imposed enormous human costs. It is thus unfortunate, although perhaps inevitable due to the fact that the $\mathrm{UN}$ report on crimes against humanity committed during the war was issued only in 2011, that none of the books on Sri Lanka engage in depth with the problem of human rights abuses before and during the final offensive. Conflict and Peacebuilding in Sri Lanka is nonetheless able to offer a glimpse of Sri Lanka's post-war order by including the recollection of a trip undertaken by Spencer in the "liberated zones" in the immediate aftermath of the fighting. ${ }^{58}$ The chapter is deliberately written in a non-academic style to preserve the feeling of the partial perspective available. Rajapaksa's rule appears to have reinforced the most illiberal 
feature of Sri Lanka's governance, concentrating power in the hands of the president and his close family members. Spencer documents the imposing presence of the security forces through the North-East and the militarization of society through the visible rise of "military fiscalism", where employment in the army is used to counterbalance economic liberalization and preserve social cohesion. ${ }^{59}$

\section{Conclusion: the future of the illiberal peace}

The Rwandan and Sri Lankan post-war governments have embraced a conservative vision of peace, where the state is seen as the main referent of security and military force is considered indispensable to maintain stability. ${ }^{60}$ Peacebuilding by illiberal means is however neither bound inevitably to fail nor to succeed. ${ }^{61}$ Indeed, when it comes to post-conflict peacebuilding apparently similar solutions can give way to very different outcomes. ${ }^{62}$ Although the means employed by the Rwandan and Sri Lankan elites might appear normatively unpalatable, a comparison with the equally illiberal Western neo-conservative statebuilding in Afghanistan and Iraq put the two countries in a positive light. Illiberal peacebuilding sacrifices individual freedoms, but can in some cases secure negative peace in the form of stability and abatement of armed violence. It can also help overcoming some of the root causes of the conflicts when is able to generate economic development and increased prosperity. Sri Lanka has known no large scale violence since the defeat of the LTTE, which has ended a conflict lasted almost thirty years. The case of Rwanda is somewhat paradoxical: the government has been continuously at war outside national borders, yet the country has experienced no violent clashes on its territory for the last fifteen years. Paradoxically, the continuous threats that the Rwandan leadership has faced might have contributed to its successes in the realm of statebuilding and economic management.

This opens important questions for the future. The first is if the experiences of the two countries are representatives of a new trend, as suggested by recent quantitative data that points out at the decline of negotiated settlements in the last decade. ${ }^{63}$

Unfortunately, the books on Rwanda suffer in part from the assumption of a 'Rwandan exceptionalism', and do not address the claim that the RPF has to be seen as part of a new wave of "Africa's illiberal statebuilders" ${ }^{64}$ On the other hand, in Conflict and Peacebuilding in Sri Lanka and in Liberal Peace in Question the argument that the reframing of conflict resolution in Sri Lanka, from 'liberal peace' to 'war against terrorism' might reflect wider trends is explicitly put forward. ${ }^{65}$ The Sri Lanka's case 
suggest that what could be called 'illiberal internationalism' is on the raise - with the support not only of non-Western powers, but also, to some extent, of the West itself.

Secondly, what are the perspectives of the two countries for the future. Is the illiberal peace in Rwanda and Sri Lanka sustainable? Is there any chance of an evolution towards a less repressive model of peace, more responsive to liberal concerns about human security and human rights?

The sustainability of the Rwandan experience is indeed a central preoccupation of all the three books under review. They agree that some aspects of the RPF project of illiberal reconstruction pose serious long-term dangers of renewed violence. As Straus and Waldorf put it, the country displays all the elements that have contributed to "the most tragic episodes of state initiated social engineering". ${ }^{66}$ Of the three books, Rwanda Fast Forward is the more focused on assessing the long-term perspectives of the Rwandan model. Esther Marjinen and Jaï van der Lijn argue that the RPF's dream of turning Rwanda into an "African Singapore" will be achievable only if the government addresses socio-economic concerns more seriously. ${ }^{67}$ More pessimistically, Jones and Verhoeven see the RPF drawn into a vicious circle of authoritarianism by its feeling of insecurity and its inability to generate popular support. ${ }^{68}$ They contend however that the most immediate threat comes from the possible collapse of intra-elite consensus, which seems a real possibility following the recent defection of high profile officials.

Sri Lanka provides a more optimistic picture. Given the country's democratic tradition, Rajapaksa's authoritarian turn and the "deep hegemony" of Sinhalese nationalism do not seem to have closed definitively the room for a liberal alternative. Because of the recent end of the conflict, the contributors are unable to make previsions about the future. However, an anti-deterministic view emerges from Peiris and Stokke's analysis of the evolution of public opinion about the peace process. They show that only when negotiations were already stalling the Sinhalese majority aligned with nationalist political forces asking for a military solution. ${ }^{69}$ It would be interesting to have the views of the contributors of the books on the recent elections, which paradoxically might prove, paraphrasing Goodhand and Korf, the unintended liberal consequences of the illiberal peace. Rajapaksa's authoritarian and ethnocratic rule appears to have in the end alienated him not only the Tamil but also the Muslim community and a part of the Sinhalese community. A breakdown of the government elite has given to Rajapaksa's detractors the possibility to join forces in order to produce the surprising election of Maithripala Sirisena and to neutralize Rajapaksa's efforts to cling to power. Although 
Sirisena is himself a former member of the Rajapaksa's government and has showed ambivalence on some delicate issues - for instance investigations for crimes against humanity committed during the war - his election could mark the end of Sri Lanka's decade of illiberal peacemaking. Notably, nationalists' bête noir Ranil Wickremesinghe has been nominated again Prime Minister and has promised to free political prisoners and to address Tamil grievances.

In conclusion, it is the merit of the five books under review to go beyond stereotypes about post-conflict peacebuilding and help us in understanding how the illiberal peace has taken shape and evolved in Rwanda and Sri Lanka. Up to now, research on peacebuilding has exhibited an ahistorical and Eurocentric bias. It has concentrated on a few highly internationalized processes, such as transitional administrations in East Timor or Kosovo or the US occupation of Iraq and Afghanistan, it has neglected both domestic dynamics and the long term dimension of the process of hybridization between international and local ideas. ${ }^{70}$ Moreover, the highly normative focus of the peacebuilding literature has not helped to understand "real existing" postconflict transitions, nor the logic pursued by countries who deviate from the 'liberal peace'. While the books under review do not aim to go beyond their single case study, it can be auspicated that in the future the issues that they tackle will be the object of more comparative research.

1. Paris, "Saving liberal peacebuilding".

2. Richmond, The Transformation of Peace. Richmond and Frank, "Liberal Hubris?". Mac

Ginty, "Hybrid Peace".

3. Smith, "Illiberal Peacebuilding".

4 Richmond and Frank, "Liberal Hubris?”.

5 Weinstein, “Autonoumous Recovery”, 5.

6 Soares de Oliveira, "Illiberal Peacebuilding", 288.

${ }^{7}$ Nadarajah and Rampton, “The Limits of Hybridity”, 18.

8 Dixon, "Emerging Consensus".

9 Kreutz, "How and When Armed Conflicts".

10 Licklider, "The Consequences of Negotiated".

11 Toft, "Ending Civil Wars".

12 Tilly, "Coercion, Capital". 
13 Herbst, States and Power. Weinstein, “Autonomous Recovery”. Englebert and Tull, "Postconflict Reconstruction". Soares de Oliveira, "Illiberal Peacebuilding",

14 Martel, "Victory in Scholarship".

15 Smith, "Illiberal Peacebuilding".

16 Straus and Waldorf, "Introduction”, 15.

17 Goodhand and Korf, "Caught in the Peace", 4.

18 Stokke, "Liberal Peace".

19 Jones, "Between Pyongyang and Singapore", 233.

20 Beswick, "The Role of the Military”, 250.

21 Verhoeven, "Nurturing Democracy".

22 Smith, "The Military Dynamics". Stokke, "Liberal Peace".

23 Philipson, "Whose War?", 108.

24 Smith, "The Military Dynamics".

25 Jones, "Between Pyongyang and Singapore".

26 Stokke, "Liberal Peace", 18.

27 Uyangoda, "Travails of State Reform".

28 United Nations, "Final Report".

29 Thies, "State Building".

30 Goodhand and Korf, "Caught in the Peace", 4.

31 Zorbas, “Aid Dependence". Hayman, "Funding Fraud?".

32 Booth and Golooba-Mutebi, "Developmental Patrimonialism".

33 Republic of Rwanda, "Peace Building Conference".

34 Goodhand and Korf, "Caught in the Peace", 15.

${ }^{35}$ Höglund and Svensson, "Fallacies of the Peace Ownership".

${ }^{36}$ Mandel, "The Meaning of Military".

${ }^{37}$ Spencer, "Reflections on an Illiberal"

${ }^{38}$ Stokke, "Liberal Peace”, 22.

${ }^{39}$ Rampton and Welikala, "Would the Real Dutugemunu”. Stokke, "Liberal Peace”. Venugopal, "The Politics of Market".

${ }^{40}$ Republic of Rwanda, "Peace Building Conference".

${ }^{41}$ Straus and Waldorf, "Introduction".

${ }^{42}$ Purdeková, "Civic Education".

${ }^{43}$ Newbury, "High Modernism”. Ansoms, "Rwanda's Post-Genocide". Thomson, "Peasant Perspectives".

${ }^{44}$ Rampton and Welikala, "Would the Real Dutugemunu”, 96. 
${ }^{45}$ Peiris and Stokke, "Liberal Peace", 161.

${ }^{46}$ Rampton and Welikala, "Would the Real Dutugemunu" Venugopal, "The Politics of Market".

${ }^{47}$ Rampton and Welikala, "Would the Real Dutugemunu", 96.

${ }^{48}$ Paris, "Saving Liberal".

${ }^{49}$ Ingelaere, "The Ruler's Drum".

${ }^{50}$ Thomson, "Peasant Perspectives".

${ }^{51}$ Straus and Waldorf, "Introduction", 4.

${ }^{52}$ Straus and Waldorf, "Introduction", 13.

${ }^{53}$ Verhoeven, "Nurturing Democracy", 265.

${ }^{54}$ Jones, "Between Pyongyang and Singapore", 243.

${ }^{55}$ Uyangoda, “Government-LTTE Peace Negotiations”. Bastian, "Politics of Market Reform".

${ }^{56}$ Venugopal, "The Politics of Market". Bastian, "Politics of Market Reform".

${ }^{57}$ Spencer, "Reflections on an Illiberal", 202.

${ }^{58}$ Spencer, "Reflections on an Illiberal"

${ }^{59}$ Spencer, "Reflections on an Illiberal", 201.

${ }^{60}$ Richmond, The Transformation of Peace.

${ }^{61}$ Smith, "Illiberal Peacebuilding".

${ }^{62}$ Heathershaw, "Towards Better Theories".

${ }^{63}$ Söderberg Kovacs and Svensson, "The Return of Victories".

${ }^{64}$ Jones, Soares de Oliveira and Verhoeven, "Africa's Illiberal”

${ }^{65}$ Stokke, "Liberal Peace", 21-22.

${ }^{66}$ Straus and Waldorf, "Introduction", 13.

${ }^{67}$ Marjinen and van der Lijn, "Rwanda 2015"

${ }^{68}$ Jones, "Between Pyongyang and Singapore". Verhoeven, "Nurturing Democracy".

${ }^{69}$ Peiris and Stokke, "Liberal Peace", 180.

${ }^{70}$ Sabaratnman, "Avatars of Eurocentrism". Nadarajah and Rampton, "The Limits of Hybridity" 


\section{Bibliography}

Ansoms, An. "Rwanda's Post-Genocide Economic Reconstruction: The Mismatch between Elite Ambitions and Rural Realities.” In Remaking Rwanda, pp. 240251.

Bastian, Sunil. "Politics of Market Reform and the UNF-led negotiations." In Conflict and Peacebuilding in Sri Lanka, pp. 132-249.

Beswick, Danielle. "The Role of the Military in Rwanda: Current Dynamics and Future Prospects." In Rwanda Fast Forward, pp. 249-264.

Booth, David and Frederick Golooba-Mutebi. "Developmental Patrimonialism? The Case of Rwanda." African Affairs 111, no. 444 (2012): 379-403.

Campioni, Maddalena and Patrick Noack. "Rwanda Fast Forward: the Many Perspectives that Make Rwanda a Unique Country." In Rwanda Fast Forward, pp. 3-12.

Dixon, Jeffrey. "Emerging Consensus: Results from the Second Wave of Statistical Studies on Civil War Termination”, Civil Wars, 11, no. 2 (2009): 121-136

Goodhand, Jonathan and Benedikt Korf. "Caught in the Peace Trap?" In Conflict and Peacebuilding in Sri Lanka, pp. 1-15.

Hayman, Rachel. "Funding Fraud? Donors and Democracy in Rwanda.” In Remaking Rwanda, pp. 118-131.

Herbst, Jeffrey I. States and Power in Africa : Comparative Lessons in Authority and Control. Princeton, N.J.: Princeton University Press, 2000.

Heathershaw, John. "Towards Better Theories of Peacebuilding: Beyond the Liberal Peace Debate." Peacebuilding 1, no. 2 (2013): 275-82.

Höglund, Kristine and Isak Svensson. "Fallacies of the Peace Ownership Approach: Exploring Norwegian Mediation in Sri Lanka.” In Liberal Peace in Question, pp. 63-76.

Ingelaere, Bert. “The Ruler's Drum and the People's Shout: Accountability and Representation on Rwanda's Hills.” In Remaking Rwanda, pp. 67-78.

Jones, Will. "Between Pyongyang and Singapore: the Rwandan State, its Rulers and the Military.” In Rwanda Fast Forward, pp. 228-248.

Jones, Will, Ricardo Soares de Oliveira and Harry Verhoeven. Africa's Illiberal StateBuilders. Working Paper 89, Refugee Studies Centre, University of Oxford, 
2012. Accessed January 14, 2015. http://www.rsc.ox.ac.uk/publications/africasilliberal-state-builders.

Kreutz, Joakim. "How and When Armed Conflicts End: Introducing the UCDP Conflict Termination Dataset.” Journal of Peace Research 47, no. 2 (2010): 243-50.

Licklider, Roy. "The Consequences of Negotiated Settlements in Civil Wars, 19451993.” The American Political Science Review 89, no.3 (1995): 681-690.

Mac Ginty, Roger. "Hybrid Peace: The Interaction between Top-down and Bottom-up Peace”. Security Dialogue 41, no. 4 (2010): 391-412.

Mandel, Robert. The Meaning of Military Victory. Boulder (CO): Lynne Rienner, 2006.

Martel, William C. "Victory in scholarship on strategy and war." Cambridge Review of International Affairs 24, n.3 (2011): 513-536

Marjinen, Esther and van der Lijn, Jaï "Rwanda 2025: Scenarios for the Future Political Stability of Rwanda.” In Rwanda Fast Forward, pp. 13-28.

Newbury, Catherine "High Modernism at the Ground Level: The Imidugudu Policy in Rwanda.” In Remaking Rwanda, pp. 223-239.

Paris, Roland. "Saving liberal peacebuilding." Review of International Studies 36, n.2 (2010): 337-365.

Peiris, Pradeep and Kristian Stokke "Liberal Peace and Public Opinion." In Liberal Peace in Question, pp. 157-182.

Philipson, Liz “Whose war? Whose peace?” In Conflict and Peacebuilding in Sri Lanka, pp. 106-118.

Purkedová, Andrea "Civic Education and Social Transformation in Post-Genocide Rwanda: Forging the Perfect Development Subject." In Rwanda Fast Forward, pp. 192-212.

Rampton, David and Asanga Welikala "Would the Real Dutugemunu Please Stand Up?” In Conflict and Peacebuilding in Sri Lanka, pp. 92-105.

Republic of Rwanda. "Peace Building Conference: Kigali Outcome Document." Ministry of Foreign Affairs, 2011. Accessed 20 February, 2015. http://www.gov.rw/newsdetails2/?tx_ttnews\%5Btt_news\%5D=410\&cHash=5af 98230a734ce2026debbc59e10dc9f.

Richmond, Oliver P. The Transformation of Peace. New York: Palgrave Macmillan, 2005.

Richmond Oliver P. and Jason Franks "Liberal Hubris? Virtual Peace in Cambodia." Security Dialogue 38 no.1 (2007): 27-48. 
Smith, Chris. "The Military Dynamics of the Peace Process and its Aftermath.” In Conflict and Peacebuilding in Sri Lanka, pp. 74-91.

Soares De Oliveira, Ricardo. "Illiberal Peacebuilding in Angola." The Journal of Modern African Studies 49, no.2 (2011): 287-314.

Claire Q. Smith. "Illiberal peace-building in hybrid political orders: managing violence during Indonesia's contested political transition." Third World Quarterly 35, n.8 (2014): 1509-1528

Söderberg Kovacs, Mimmi, and Isak Svensson. “The Return of Victories?” Paper presented at the seventh General Conference of the European Consortium for Political Research (ECPR), Bordeaux, September 4-7, 2013. Accessed Jaunary 15, 2015. http://ecpr.eu/Filestore/PaperProposal/8b5c9fb5-9173-47da-969f28d8124cbc67.pdf.

Spencer, Jonathan. "Reflections on an Illiberal Peace." In Conflict and Peacebuilding in Sri Lanka, pp. 201-212.

Straus, Scott and Lars Waldorf "Introduction: Seeing Like a Post-Conflict State.” In Remaking Rwanda, pp. 3-24.

Stokke, Kristian. “Liberal Peace in Question: The Sri Lanka Case.” In Liberal Peace in Question, pp. 1-34.

Thies, Cameron G. "State Building, Interstate and Intrastate Rivalry: A Study of PostColonial Developing Country Extractive Efforts, 1975-2000.” International Studies Quarterly 48, n. 1 (2004): 53-72.

Thomson, Susan. "Peasant Perspectives on National Unity and Reconciliation: Building Peace or Promoting Division?” In Rwanda Fast Forward, pp. 96-112.

Tilly, Charles. Coercion, Capital and European States: AD 990 - 1992. Cambridge (MA): Blackwell, 1990.

Toft, Monica Duffy. “Ending Civil Wars: A Case for Rebel Victory?” International Security 34, no. 4 (2010): 7-36.

United Nations (UN). "Final report of the Group of Experts on the Democratic Republic of the Congo, prepared in pursuance of paragraph 4 of Security Council resolution 2021 (2011)”, 12 October 2012. Accessed March 13, 2015. http://www.un.org/sc/committees/1533/egroup.shtml.

Uyangoda, Jayadeva. “Government-LTTE Peace Negotiations in 2002-2005 and the Clash of State Formation Projects." In Conflict and Peacebuilding in Sri Lanka, pp. 16-38. 
Uyangoda, Jayadeva. "Travails of State Reform in the Context of Protracted Civil War in Sri Lanka.” In Liberal Peace in Question, pp. 35-62.

Venugopal, Rajesh. "The Politics of Market Reform at a Time of Ethnic Conflict: Sri Lanka in the Jayewardene Years.” In Liberal Peace in Question, pp. 77-102.

Verhoeven, Harry. "Nurturing Democracy or into the Danger Zone? The Rwandan Patriotic Front, Elite Fragmentation and Post-liberation Politics." In Rwanda Fast Forward, 265-280.

Weinstein, Jeremy. "Autonomous Recovery and International Intervention in Comparative Perspective.” Center for Global Development, Working Paper 57 (2005). Accessed January 14, 2015.

http://www.cgdev.org/publication/autonomous-recovery-and-internationalintervention-comparative-perspective-working-paper.

Zorbas, Eugenia. “Aid Dependence and Policy Independence: Explaining the Rwandan Paradox.” In Remaking Rwanda, pp. 103-107. 